УДК 811.111:81’38:81’42:34

DOI https://doi.org/10.26661/2414-1135-2021-83-22

\title{
ЛЕКСИКО-СТИЛІСТИЧНІ ЗАСОБИ ВЕРБАЛІЗАЦІЇ ЕКСПРЕСИВНОСТІ У ТЕКСТІ РЕКЛАМИ
}

\author{
Куспісь Н. Б. \\ асистент кафедри іноземних мов, \\ аспірант кафедри англійської філологіі \\ Львівський національний університет імені Івана Франка \\ вул. Університетська 1, Львів, Украӥна \\ orcid.org/0000-0003-4221-9281 \\ kn2013@ukr.net \\ Саноцька Л. Г. \\ кандидат філологічних наук, дочент, \\ дочент кафедри англійської філології \\ Львівський національний університет імені Івана Франка \\ вул. Університетська 1, м. Львів, Украӥна \\ orcid.org/0000-0003-0605-3587 \\ larysa.sanotska@lnu.edu.ua
}

Ключові слова: реклама, рекламний текст, рекламний слоган, мовні засоби, стилістичні прийоми, лексичні прийоми.
Стаття присвячена лінгвістичному дослідженню англомовних рекламних текстів. У статті аналізуються лексичні та стилістичні мовні засоби, використання яких сприяє збагаченню експресивності тексту, викликає інтерес у споживача та посилює бажання придбати товар, що рекламується. Актуальність теми дослідження полягає у тому, щоб виявити та продемонструвати величезний спектр використання лексичних та стилістичних мовних засобів у рекламному тексті, який досі залишається не до кінця дослідженим та перебуває у постійному центрі уваги мовознавців. У статті розглянуто поняття реклами одного із провідних засобів комунікації та основного інструмента у маркетинговій галузі, який застосовують для передачі інформації щодо певних продуктів чи послуг широкому загалу. Особливу увагу приділено рекламним текстам та слоганам реклами косметичних засобів, продуктів харчування тощо. У тексті детально розглядаються такі лексикостилістичні засоби: синоніми, антоніми, омоніми, полісемія, риторичні фігури (звертання, антитеза, евфемізми, персоніфікація, заперечення, гра слів), експліцитний та імпліцитний способи розповсюдження інформації, еліптичні конструкції, різноманітні форми діалогічності. У статті зазначається, що у створенні рекламних текстів та слоганів важливим є ретельний відбір мовних засобів, які відповідатимуть стилістичній тональності відповідно до конкретної комунікативної ситуації, характеру адресата, середовища функціонування та інтенції. У процесі аналізу сорока двох рекламних текстів виявлено найбільшу частоту застосування лексичних мовних засобів у текстах реклами косметичних засобів. Виявлено також і найбільш використовувані стилістичні мовні засоби у рекламі продуктів харчування та косметичних засобів. Таким чином, від коректного застосування кожного лексичного (синоніми, антоніми, омоніми, полісемія, експліцитність та імпліцитність) та стилістичного (риторичні фігури, еліптичні конструкції, форми діалогічності) мовних засобів буде залежати ефективність сприйняття реклами аудиторією. 


\title{
LEXICO-STYLISTIC MEANS OF VERBALIZATION OF THE EXPRESSIVENESS IN THE TEXT OF ADVERTISING
}

\author{
Kuspis N. B. \\ Lecturer at the Department of Foreign Languages, \\ Postgraduate Student at the Department of English Philology \\ Lviv Ivan Franko National University \\ Universytetska str., 1, ,Lviv, Ukraine \\ orcid.org/0000-0003-4221-9281 \\ kn2013@ukr.net \\ Sanotska L. G. \\ Doctor of Philosophy, Associate Professor, \\ Associate Professor at the Department of English Philology \\ Ivan Franko National University of Lviv \\ Universytetska str., 1, Lviv, Ukraine \\ orcid.org/0000-0003-0605-3587 \\ larysa.sanotska@lnu.edu.ua
}

Key words: text of advertisement, advertising slogan, language tools, stylistic devices, lexical devices.
The article is devoted to the linguistic study of the advertising texts in English. The usage of lexical and stylistic language tools, which are analysed in the article, promotes the enhancement of expressiveness in the text, provoke consumer interest and increase their desire to buy the goods which are advertised. The topicality of this research lies in identification and demonstration of a vast range of lexical and stylistic language used in the text of advertisement, which still remains understudied. That is why it remains in the focus of research for linguists. The concept of advertising, as one of the leading tools of communication, is also examined in the article. Advertising is considered not only to be an important tool in the marketing industry, but it is also one of the most widely used ways of conveying information about certain products or services for the general population. Such lexical and stylistic means as synonyms, antonyms, homonyms, polysemy, rhetorical figures (treatment, antithesis, euphemisms, personification, negation, play on words), explicit and implicit ways of dissemination of information, various forms of dialog, because in the process of making the texts of advertisement and slogans, the author carefully selects language tools which will correspond to the style in accordance with specific communicative situation, the nature of the recipient, the operating environment and the intention. The analysis of forty two texts of advertisement revealed the highest frequency of the use of lexical language tools, such as synonyms, antonyms, homonyms, polysemy, explicit and implicit ways of disseminating information, especially in the texts advertising cosmetics. We identified such stylistic tools as rhetorical figures, elliptical constructions, various forms of dialogues in the advertising of food and cosmetics. Thus, the effectiveness of consumers' perception of the advertisement will depend on the use of each lexical (synonyms, antonyms, homonyms, polysemy, explicit and implicit ways of disseminating information) and stylistic (rhetorical figures, elliptical constructions, forms of the dialogues) language tools effectively.
Постановка проблеми. Сьогодні у період швидкого розвитку суспільства, використання прогресивних засобів обміну інформацією постає нагальна проблема створення рекламних текстів.
Вже протягом багатьох років реклама залишається постійним об'єктом аналізу та дослідження різних вчених. Крім того, протягом останніх десяти років було проведено велику кількість лінгвістичних 
досліджень щодо вивчення текстів масової комунікації, зокрема текстів реклами. Нині реклама займає важливе місце в інформаційному просторі, впливає на поведінку людей та керує нею, водночас маніпулюючи їхньою свідомістю. Саме тому те значне місце, яке вона займає, впливає на наше життя, оскільки від іiі результативності залежить вирішення різноманітних важливих завдань у економіці та суспільстві.

Вперше сучасну рекламу почали досліджувати на початку 80 -х років минулого століття такі відомі вчені, як Д. Розенталь, М. Кохтев. На думку Т.В. Колісниченко, саме вони застосували лінгвістичний аналіз щодо текстів друкованої реклами в книзі «Мова рекламних текстів» [2, с. 93-94]. Проте Л.В. Музикант вважає, що для більшості вчених того часу реклама була одним із компонентів маркетингу, а також була достатньо переконливим та дешевим прийомом, щоб повідомляти покупців про певний товар або послугу [4, с. 12].

На думку Т.Н. Лившиц, для створення переконливого рекламного тексту, який зможе привернути увагу споживача та зацікавити у придбанні певного виду продукту, необхідно забезпечити правильний підбір та влучне використання мовних засобів. Саме тому основним джерелом урізноманітнення та удосконалення тексту реклами $\epsilon$ використання лексико-стилістичних засобів синонімів, антонімів, омонімів, ономастичної лексики, образних засобів мови [3, с. 174].

Актуальність дослідження випливає 3 того факту, що реклама у житті сучасного суспільства займає важливе місце, тому постає необхідність аналізу використання певних мовних одиниць для дослідження їхнього впливу на свідомість споживача. Аналіз експресивності лінгвістичних засобів, що застосовуються в сучасній англомовній рекламі, спрямований на дослідження засобів для вирішення згаданої проблеми.

Основна мета дослідження - виявити тенденції експресивності застосування різних мовних одиниць, що використовуються під час створення реклами.

Окрім того, це дослідження зосереджене на аналізі експресивності певних мовних засобів, що використовуються в рекламному тексті. Мета дослідження передбачас вирішення кількох завдань:

- дати визначення поняттю реклами;

- окреслити структуру рекламного тексту;

- розкрити значення рекламного дискурсу;

- дослідити зв'язок між частинами рекламного тексту та мовними засобами, що використовуються в них з метою створення певного ефекту;

- забезпечити аналіз рівня експресивності мовних засобів, що застосовуються в рекламному тексті.
Об'єкт дослідження - англомовні тексти реклами косметичних засобів, продуктів харчування, здоров'я, автомобілів, взуття, прикрас. Предмет дослідження - експресивність лексико-стилістичних засобів у англомовному тексті реклами.

Матеріалом дослідження слугував корпус із сорока двох англомовних рекламних текстів журнальної реклами, а також текстів інтернет-реклами. Що стосується основних критеріїв відбору рекламних текстів, то основна увага була зосереджена на наявності експресивності - ефекту, створеного завдяки влучному використанню мовних засобів у конкретних рекламних текстах. Основна частина текстів реклами взята 3 іноземних журналів, таких як Women's Health, Jet, Journal of Diarrhoeal Diseases Research, Orange Coast, Marie Claire, New York, The Ultimate Insider's Guide to New York. Також нами досліджувалась реклама 3 різноманітних англомовних інтернет-сайтів, представлена у формі слоганів.

Виклад основного матеріалу дослідження. Отже, реклама становить непростий феномен протягом багатьох років. Велика кількість науковців продовжує досліджувати цей феномен і дотепер. Зокрема, М. Хосней стверджує, що реклама належить до особливого виду дискурсу, та зазначає, що вона безпосередньо позначається на структурі мови, стилі життя та $є$ суттю щоденного спілкування. А В.В. Михайленко акцентує увагу на тому, що реклама виконує роль маркетингового інструменту у туристичній сфері, де потенційні клієнти ухвалюють рішення, керуючись ментальними образами запропонованого продукту у варбалізованій комунікації [2, с. 94].

Що стосується трактувань рекламного тексту, то варто зазначити, що рекламний текст розглядається як сукупність аудіовізуальних засобів у довільній комбінації, спрямованих на реципієнта 3 метою забезпечення запланованої взаємодії, пов'язаної з об'єктом рекламування. Основне завдання реклами - зовнішнім виглядом привернути увагу майбутніх покупців, зацікавити, а також переконати придбати певний товар. До основних структурних елементів рекламного тексту відносять:

- заголовок, який сприяє приверненню уваги до тексту, зацікавлює покупця. Саме через це він повинен бути ефективним за своїм впливом та зрозумілим за змістом;

- підзаголовок - це своєрідний місток між заголовком і основним текстом;

- основний текст виконує обіцянки, які містяться у заголовку. Основний текст рекламного повідомлення буває таких типів, як розповідний, зображальний, оригінальний, а також може бути написаний у формі монологу чи діалогу [7, с. 2-3]. 
Крім того, рекламний текст за своєю структурою ділиться на три такі частини:

- вступ полягає в тому, що рекламодавець ознайомлює споживача з темою реклами;

- основна частина містить у собі мету рекламної пропозиції, у якій зазначаються основні переваги товару чи послуги;

- у висновку підводиться підсумок запропонованого, а також у ньому розміщується кінцева фраза - слоган, мета якого - спонукати споживачів до здійснення дії [7, с. 3].

Таким чином, бачимо, що при створенні певного типу тексту важливим елементом залишається його структура. Ї̈̈ становлення $є$ надзвичайно важливим етапом, від якого буде залежати розв'язання проблем аналізу тексту, його розуміння та текстотворення.

Оскільки науковиця М. Хосней стверджувала, що термін «реклама» належить до особливого типу дискурсу, то варто розкрити саме поняття «дискурс», а також «рекламний дискурс». Отже, Т.В. Колісниченко зазначала, що поняття «дискурс» належить до міждисциплінарного типу, оскільки $є$ надзвичайно розповсюдженим у різних галузях мовознавства, що спричинило велику кількість тлумачень даного поняття. До ключових дефініцій дискурсу Т.В. Колісниченко відносить такі: дискурс як мовлення, здійснене у формі усного чи письмового висловлювання; дискурс як паралельність мовного, когнітивного й комунікативного аспектів; дискурс як співіснування вербальних та невербальних знаків, призначених для задоволення потреб у певній комунікативній сфері. Отже, до основних особливостей дискурсу належать такі: смислова дифузність, змінний обсяг універсальних та специфічних ознак, різнорідна структура та широка типологія, що і призводить до його багатоаспектного використання в різноманітних галузях лінгвістики [2, с. 94].

Акцентуючи увагу на рекламному дискурсі, можемо сказати, що його відносять до інституційного виду, який має сталий та семіотичний характер. Саме через рекламу реалізується сугестивний ефект на реципієнта, тобто відбувається процес управління посткомунікативними діями чи поведінкою реципієнта. Отже, бачимо, що у рекламній комунікації дискурс виконує дуже важливу роль. Від ефекту, який він справляє на реципієнта, буде залежати результат рекламної комунікації $[2$, c. 94$]$.

Що стосується зв'язку між частинами рекламного тексту та мовними засобами, що використовуються в них $з$ метою створення певного ефекту, то варто зазначити, що рекламний текст складається 3 вербальних (слоган, заголовок, основний рекламний текст) та невербальних елементів (шрифт, колір, візуально-графічні засоби), між якими існує важливий зв'язок. Проте рекламний текст не завжди містить кожен із цих компонентів. Якщо текст написаний граматично вірно та ефективно $з$ погляду застосовуваних мовних одиниць, стилістично продуманий і супроводжуваний певним зображенням, а також компоненти структури рекламного тексту можуть заміняти та доповнювати один одного, тоді рекламний текст справить очікуваний ефект на реципієнта [2, с. 94].

У сорока двох проаналізованих у цьому дослідженні рекламних текстах ми звертали особливу увагу на вживання таких лінгвостилістичних засобів: синонімів, антонімів, омонімів, полісемії, риторичних фігур (звертання, антитези, евфемізмів, персоніфікації, заперечення, гри слів), експліцитного та імпліцитного способів розповсюдження інформації, еліптичних конструкцій, різноманітних форм діалогічності. Так, щодо реклам про косметичні засоби, комерційні товари, продукти харчування, здоров'я ми зауважили, що автори особливу увагу приділяють застосуванню саме лексичних мовних засобів (синонімів, антонімів, омонімів, експліцитного та імпліцитного способів розповсюдження інформації), тому що вважають, що саме ці засоби сприяють збагаченню рекламного повідомлення, а також виступають потужним засобом привернення уваги споживача до купівлі товару. Приклади цього аналізу наведені у рекламних текстах.

Синоніми у рекламному тексті виконують різноманітні функції, проте однією з найважливіших $€$ функція збагачення повідомлення, аби уникнути повторів і тим самим посилити інтерес до товару. Ми дослідили рекламні тексти, пов'язані з продуктами харчування та косметикою, в яких можна простежити використання синонімів 3 метою вербалізації функціонально спрямованої експресивності реклами. Наприклад, у рекламі "Eat good. Look great" [39, с. 96] використано два синоніми good, great. 3 даного контексту стає зрозуміло, що клієнт отримає задоволення від шоколадного батончика, який він спробував на смак. Наведемо інший приклад. У рекламному тексті "Its unique blend of rich hydrating cream and skin nourishing oil turns extra dry skin into extra soft, extra smooth, extra beautiful skin" використано синоніми soft, smooth, які вказують на те, що, випробувавши олійку для тіла "Dove", ви відчуєте, що шкіра буде гладенькою та шовковистою [35, с. 65].

Використовуються в тексті реклами також і антоніми. Наприклад, у рекламі продуктів харчування та побутової хімії частотність використання градуальних ступенів протилежностей, виражених антонімами, помітно зростає. Так, у реченні "First it makes you weak. Then it makes you strong” помітна різниця у стані [19, с. 17]. Тобто, якщо скуштуєш шоколад, то спочатку відчуєш 
себе слабким від того, що шоколад виявиться надзвичайно смачним, а потім сильним, отримавши від нього величезне задоволення. Крім того, дуже часто антоніми застосовуються і у рекламних слоганах. Наприклад, у рекламному слогані для ліків "Burn more fat. See more thin" [14, с. 169] сказано, що, приймаючи ці таблетки для схуднення, можливо легко та швидко позбутися зайвої ваги та стати струнким. Отже, найчастіше антонімія у текстах реклами формується через зміст, а також вона породжує нові смислові відношення.

Яскравою ознакою проаналізованих текстів $є$ застосування омонімів. Найчастіше їх вживають у тексті реклами задля створення ефекту каламбуру або гри слів. Він полягає у вживанні засобу омонімії в одній фразі, щоб зробити їі більш цікавою для аудиторії. Наприклад, у рекламі організації здоров'я “Go Ahead with AHEAD” один із елементів «Ahead» $є$ омонімом та означає «вперед» поєднаний з іншим елементом «AHEAD»- акронімом [25, с. 255]. Ми вважаємо, що завдяки такому поєднанню у цій рекламі досягається ефект мовної гри. Крім того, дане явище простежується і у рекламі прикрас, зокрема у слогані “Every kiss begins with Kay" [31]. Гра слів у даному випадку полягає у тому, що рекламодавці вміло використали слово “поцілунок”, яке починається з літери "K", а приховане подвійне значення передбачає те, як компанія «Кей» приведе до поцілунків та любові через придбання їхньої продукції. На основі цього робимо висновок, що саме завдяки омонімії та ефекту мовної гри створено лінгвістичне підгрунтя, яке спонукає до виникнення особливого інтересу споживача до товару.

Експліцитний та імпліцитний способи розповсюдження інформації є основними способами вираження комунікативного наміру у рекламному тексті. Як відомо, експліцитність зумовлює правильну та чітку інтерпретацію тексту реклами, а імпліцитність означає непряму передачу інформації. Вважається, що часте використання імпліцитності інформації пов'язане із наявністю мовних та позамовних факторів. Зокрема, до позамовних факторів належить бажання передати велику кількість інформації, використавши при цьому малу кількість слів, а також потреба у забезпеченні текстової інформації за допомогою розгортання та спонукання. Що стосується мовних факторів, то ми можемо виокремити оказіональне використання розмовного стилю та наявність конденсації і компресії. Саме імпліцитність, як вважає низка вчених, зокрема Л.В. Кардаш, Ф.С. Бацевич, В.Х. Багдасарян, Е.Й. Шендельс, М.В. Нікітін, В.Н. Мороз, К.А. Долинін, В.А. Кухаренко, С.Д. Кацнельсон, В.І. Кононенко, є найбільш розповсюдженою тенденцією щодо розповсюдження інформації [6, с. 200]. Так, у текстах комерційної реклами ми побачили, що автори використовують імпліцитність, тому що передача інформації непрямим шляхом сприяє створенню експресивності, оскільки така інформація має суттєво захопити увагу споживача. У рекламі мобільних телефонів "Nokia. Connecting people" [21] у фразі Connecting people міститься підвищений градус розпізнавання реклами, оскільки ця фраза $є$ гаслом компанії, тобто фраза дає нам зрозуміти, що ідеться саме про компанію 3 продажу техніки, а саме мобільних телефонів. До основних індикаторів імпліцитної інформації можна віднести назви міст, країн, вулиць. Вони постають певними поручителями найвищої характеристики об'єкта, що рекламується, наприклад: “ТOMMY - the new American fragrance" [46, с. 24]. Широко використовується часова лексика: "Now blend away gray with the sure thing for a natural look" [36, с. 27]. Вживаються числа, які являють собою символи імпліцитності оцінювання предмета реклами: “Reverso. Avantgarge since 1931" [30, с. 7]. Експліцитність реклами можна побачити у такому рекламному слогані напоїв: "Cheat Death. The antioxidant power of pomegranate juice" [38], оскільки у даному рекламному слогані пляшка соку зображується із петлею на шиї. Крім того, саме зображення пляшки з серцем $\epsilon$, на нашу думку, певною мірою графічною персоніфікацією. Метою цього, як ми вважаємо, є привернути увагу аудиторії ще перед вербалізованою рекламою.

Полісемія належить до одного із видів передачі одночасно двох значень у тексті реклами - прямого та переносного. Так, у рекламах про продукти харчування автори особливу увагу надають полісеміі, яку вони вважають значимою для досягнення ефекту двох протилежних значень. У рекламі автомобілів “The power of dreams” [24] під словом “power” мається на увазі або ж автомобіль, або ж потужний двигун. Отже, цей слоган можемо інтерпретувати таким чином: автомобіль мрій чи двигун мрій. Ще одним яскравим прикладом застосування полісемії у тексті реклами слугує такий рекламний слоган: "The drive of your life" [24], де слово “drive” має одночасно три значення - автомобіль, поїздка та прагнення. Таким чином, даний слоган можемо трактувати трьома способами: автомобіль твого життя, поїздка твого життя чи прагнення твого життя.

У рекламних текстах про продукти харчування, косметичні засоби, здоров'я, телебачення особлива увага приділяється використанню стилістичних мовних засобів, тому що саме ці засоби сприяють лаконічності, доступності, оригінальності інформації та експресивності тексту. До стилістичних засобів у рекламних текстах відносять риторичні фігури, зокрема звертання, запитання, антитезу, евфемізми, персоніфікацію, 
заперечення, гру слів, які відносять, на думку Е.В Клюєва, «по-перше, до будь-якої форми, що містить думку, по-друге, фігура - це свідоме відхилення в думці чи у вираженні від звичайної, повсякденної і простої форми» [1, с. 174]. У наступних прикладах проілюстроване застосування перелічених засобів.

У рекламних текстах прослідковується часте вживання заперечних займенників, таких як never/ ніколи; nobody, по опе / нixто; nопе, по/ жоден. Наприклад, у рекламах про косметичні засоби, продукти харчування, телебачення саме заперечення допомагає виділити неповторність та важливість певних товарів, наприклад: "Never has a perfume provoked such emotion" [48, c. 77]; "M\&Ms melt in your mouth, not in your hand" [17]; "Sometimes you feel like a nut, sometimes you don' $t$ " [15]; "Please Don't Squeeze the Charmin" [34]; "It's not TV, it's HBO" [44]. Отже, лексико-граматичні структури заперечення функціонують у рекламних текстах як емоційні стимулятори.

Висока частотність використання лексико-граматичних форм звертання виявлена у рекламних текстах косметичних засобів, які застосовуються в якості спонукання, наприклад: "Youth is in your genes. Reactivate it"; "Clinically proven. Use AM and PM for powerful skin results in 7 days" [12, с. 194]. Таким чином, найчастіше лексико-граматичні форми звертання виражаються у формі дієслів наказового способу, при цьому застосовується форма прямого спонукання.

Крім того, у текстах реклами трапляється висока частотність застосування риторичних питальних речень, які містять у своїй мовній структурі твердження або заперечення та передбачають відповідь. Наприклад: “Wouldn't you really rather have a Buick?" [47]; "Have you ever had a bad time in Levi's?" [27].

У рекламах інтернет-магазинів та курсів водіння антитеза вживається для того, щоб актуалізувати функцію переконання завдяки їі підкресленому зіставленню протилежних, проте подібних між собою понять. Крім того, як засіб контрасту антитеза застосовується для підкреслення та наголошення на перевагах предмета рекламування, а також для наділення рекламного повідомлення додатковою експресивністю [4, с. 184]. Щоб краще прослідкувати застосування цієї риторичної фігури, розглянемо такі приклади: "Big Brands - Low Prices" [11]; "Cheap, Easy, Fast” [45]; "Beauty outside. Beast inside" [42].

У журнальній рекламі виявлено часте застосування мовної гри, котра, на думку I.Е. Сніховської, $\epsilon$ «процесом і результатом свідомої лінгвокреативної діяльності індивіда, спрямованої на нестереотипне варіювання форми та змісту мовних одиниць на ігровому регістрі комунікації з метою впливу на емоційну та/або інтелектуальну сферу адресата» [5, с. 10]. Висока частотність вживання мовної гри виявлена у таких видах реклами, як реклама напоїв та косметичних засобів. Зокрема, у рекламі напоїв переважає застосування мовної гри за допомогою експресивних та оригінальних форм слів, а саме вербальних та невербальних засобів [5, с. 6], наприклад: “Men just can't help acting on impulse" [10]. Так, у різноманітних банерних рекламах та рекламах косметичних засобів ми помітили, що автори особливу увагу надають власне мовній грі - каламбуру, тому що вважають, що його застосування сприятиме несподіваному ефекту об'єднання чи зіткнення двох несумісних значень в одній фонетичній (графічній) формі. Розглянемо такі рекламні приклади: vitamins nightamins: "New High-Potency Night-A-Mins" [40]; be - bee: "Don't Worry... Bee Happy! Send a Smiley Greeting" [18]; week - weak: "Seven days without EXERCISE makes one weak!'[13].

Що стосується евфемізму, який як термін був вперше запроваджений такими австралійськими дослідниками, як К. Алан та К. Барідж, то цей засіб у значній кількості був виявлений у рекламах косметичних засобів та місць для людей 3 обмеженими можливостями. Евфемізм, на думку К. Алана, вживається як альтернатива до небажаного виразу з метою уникнення можливої втрати власної репутації (loss of face) або через образу репутації адресата, або якоїсь третьої сторони [8, с. 221]. Саме тому високочастотне використання цього засобу у рекламах косметичних засобів та тютюнопаління сприяє створенню ефекту перебільшення завдяки гіперболізації переваг товарів i применшенню їх недоліків. Розглянемо випадки вживання евфемізмів у рекламних текстах, зазначених вище: "Children of parents who smoke, get to heaven earlier” [41]. Тут слово «смерть» замінено на позитивніший вираз «get to heaven», який виступає в даному контексті евфемізмом. Посилення ідеї відбувається завдяки візуалізації, де дитина зображується 3 ореолом на голові. Таким чином, пряме вираження смерті замінено на евфемістичний варіант «шлях до неба». Отже, евфемізми у даному випадку виступають у ролі мовних фігур, спрямованих на заміну грубих, неналежних слів на непрямі та пом'якшувальні з метою уникнення непорозумінь та конфліктів у процесі комунікації.

Персоніфікація належить до одного 3 найчастіше застосовуваних прийомів реклами. Вона полягає у перенесенні людських якостей на товари чи послуги, що рекламуються [26, с. 62]. Найчастіше персоніфікація представлена у тексті реклами за допомогою дієслів. Так, у рекламі туалетного паперу "Cottonelle. Looking out for the family" [16, с. 29] туалетний папір здатний потурбуватися про нашу шкіру через свою м'яку 
структуру та наявність у ньому екстракту алое вера. Поряд з рекламою напоїв персоніфікацію використовують і у рекламі автомобілів, зокрема: "The car that cares" [9], де машина наділяється людськими якостями та здатна забезпечити турботу та комфорт. Отже, у наведених рекламних текстах створюється певна образність, яка допомагає споживачу краще зрозуміти, що саме мається на увазі під конкретним рекламним текстом.

Еліптичні конструкції належать до найуживаніших стилістичних мовних прийомів у текстах реклами завдяки експресіі, яка проявляється у прямій здатності спонукати до дії, коли одна частина рекламного повідомлення є зазвичай скороченою, а основна увага акцентується на невідомій частині. Так, у рекламі побутової хімії “I kеер my hands clean; Why can't he?" [28]; "Does she... or Doesn't she?" [33] пропущено об'єкт рекламування, через що споживачеві буде важко зрозуміти, про який товар ідеться.

Графічні мовні засоби належать до невербальних мовних засобів та найчастіше застосовуються у текстах друкованої реклами й відтворюються через зміну написання слів 3 конкретною метою. Їх застосування зумовлене тим, щоб завдяки візуалізації або риторично привернути увагу, викликати певні асоціації, призвести до емоційного впливу та підштовхувати до роздумів. До цієї групи відносять візуальні мовні засоби, про які ми згадували вище, аналізуючи експліцитність такого рекламного слогану (див. стор. 8): "Cheat Death. The antioxidant power of pomegranate juice" [38], де зображено персоніфіковану пляшку, яка нагадує людину з серцем. Крім того, звернення «Обманюй смерть», яке написане великим, чітким шрифтом і надруковане чорним кольором, додатково приверне увагу до цієї реклами графічним способом та надасть рекламному тексту серйозного тону. Це звертання до суспільства, яке прагне здорового способу життя, але «обдурити смерть» не здатне, справляє ефект на емоційному рівні. Також часто в тексті спостерігається використання великих літер, наприклад: “НAVE A BREAK, HAVE A KIT KAT" [32], які через прийом капіталізації сприяють приверненню уваги споживача до товару.

Ще однією важливою особливістю рекламного тексту $є$ часте використання різних форм діалогу. Найбільш застосовуваними формами є займенники «ти» і «ви», які найчастіше вживаються у формі прямих звертань, на яких робиться основний акцент у рекламі, щоб привернути увагу та спрямувати рекламне повідомлення до конкретної людини. Щоб побачити цю особливість, варто розглянути такі приклади: “Үou can do this" [22, c. 35]; "First it makes you weak. Then it makes you strong" [18, c. 17]; "It's everywhere you want to be" [29]; "Why settle for a basic cleanser when at the same time you can do more for your skin with Olay" [37, с. 11]. Також у текстах реклами ми натрапили на застосування присвійних займенників «ваш», «твій» та «наш»: “This exclusive formula works with your skin's unique chemistry, accelerating your cell renewal process. See what it can do for you" [23, c. 4]; "The Supernova Cushion featuring For Motion is designed for your motion. The freely-movable heel unit adapts to your individual footstrike, giving you a smoother and more comfortable ride" [43, c. 21]; "Shower your skin in luxury" [20, c. 61]. Отже, форми діалогічності в перелічених рекламних текстах використовуються 3 метою підсилення повідомлення контактним чи психологічним впливом для наближення до споживача та привернення уваги завдяки прямим звертанням.

Висновки та перспективи подальших розробок. Таким чином, наш аналіз свідчить про те, що дослідження мовних особливостей англомовних рекламних текстів $є$ достатньо складним та багатогранним процесом. Дослідження тенденцій експресивності лексико-стилістичних мовних засобів у наявних рекламних текстах переконливо продемонструвало той факт, що поняття реклами $\epsilon$ доволі складним, що існують розбіжності у тлумаченні терміна реклами і що як текст реклами, так $\mathrm{i}$ виразові засоби експресивності в тексті англомовної реклами потребують подальшого ретельного дослідження. Окрім того, ми розглянули структуру рекламного тексту, яка слугує базою тексту і $\epsilon$ доволі специфічною, адже аналіз можливий лише за умови повного розуміння структури такого тексту. Ми також розглянули поняття рекламного дискурсу, оскільки реклама належить до певного типу дискурсу, що зумовлює застосування вербальних та невербальних компонентів, функцією яких $\epsilon$ привернення уваги споживачів до рекламованого товару через рекламне повідомлення. Ми дійшли висновку, що між частинами тексту та мовними засобами існує певний зв'язок, який проявляється у тому, що вербальні та невербальні компоненти в тексті можуть взаємодоповнювати один одного, а також сприяти реалізації конкретного рекламного ефекту на реципієнта. Отже, дослідивши сорок два тексти англомовної реклами, ми побачили, що кожне рекламне повідомлення, розглянуте вище, містить яскраво виражену тенденцію експресивності, яка втілена у тексті завдяки влучному використанню одночасно двох груп мовних засобів лексичних та стилістичних. Також ми виявили, що найбільш насиченою лексико-стилістичними засобами є реклама косметичних засобів та продуктів харчування.

Подальше дослідження експресивності, вираженої лексичними та стилістичними мовними засобами у тексті реклами, буде базува- 
тися на більшій базі рекламних текстів і буде спрямоване на підтвердження чи спростування висновків, яких ми дійшли у цьому аналізі. Вважаємо, що подальше дослідження буде актуальним, адже текст англомовної реклами завжди перебуватиме в центрі уваги лінгвістів, оскільки від коректного застосування експресивних засобів залежить, який ефект дана реклама справить на споживача, а також чи захоче він придбати певний товар і скористатися конкретним видом послуг.

\section{ЛІТЕРАТУРА}

1. Клюев Е.В. Риторика (Инвенция. Диспозиция. Элокуция) : учеб. пос. для вузов. М. : Издательство ПРИОР, 2001. С. 272.

2. Колісниченко Т.В. Рекламний дискурс: поняття, ознаки та функції. Закарпатські філологічні студіï. Ужгород : Гельветика, 2020. № 13. С. 93-96.

3. Лившиц Т.Н. Специфика рекламы в прагматическом и лингвистическом аспектах : дисс. ... канд. филол. наук : 10.02.19. Таганрог, 1999. C. 354

4. Музикант В.Л. Теория и практика современной рекламы / под ред. В.Л. Музыканта. М. : Евразийский регион, 1998. С. 12, 400.

5. Сніховська I.Е. Механізми, засоби та прийоми мовної гри в сучасній англійській мові : автореф. дис. ... канд. філол. наук : 10.02.04 «Германські мови». Запоріжжя, 2005. С. 6.

6. Ткачук-Мірошниченко О.Є. Імплікація в рекламному дискурсі (на матеріалі англомовної комерційної реклами) : дис. ... канд. філол. наук : 10.02.04. К., 2001. С. 201.

7. Тюрина С.Ю. О понятиях «рекламный дискурс» и «рекламный текст». Вестник ИГЭУ. № 1. C. 1-3.

8. Allan K., Burridge K. Euphemism and Dysphemism: language used as shield and weapon. Oxford: Oxford University Press, 1991. $263 \mathrm{p}$.

9. Automobile Slogans. URL: https://www. advergize.com/slogans-list/car-slogans/.

10. Beale B. Men can't help acting on impulse. ABC Science. 2003. URL: https://www.abc.net.au/ science/articles/2003/12/11/1007888.htm.

11. Big Brands. Low prices. URL: https://www. facebook.com/brandmywrist.

12. Bittner J.R. Mass Communication. Boston : Allyn and Bacon, 1996. 235 p.

13. Buratty E. EBFitness. Stop curing health problems. Prevent them. URL: http:// ericburattyfitness.com/seven-days-withoutexercise-makes-one-weak/.

14. Burn more fat. See more thin. Women's Health. № 4. 2008, 169. URL: https://books.google.com.ua/ books?id=1sUDAAAAMBAJ\&pg=PA $11 \& 1 \mathrm{pg}=$ PA11\# $\mathrm{v}=$ onepage $\& q \& \mathrm{f}=$ false.
15. ChocolateWiki.URL:https://chocolate.fandom.com/ wiki/Almond_Joy.

16. (2004). Cottonelle. Lab Tested for Gentless. Jet, 1, 29. URL: https://books.google.com.ua/ books? id=5LUDAAAAMBAJ\&pg=PA29\& lpg $=$ PA29\&dq $=$ Cottonelle $\# \mathrm{v}=$ onepage $\& \mathrm{q}=$ Cotto nelle $\& \mathrm{f}=$ false.

17. Cravings of a Food Scientist. URL: https:// cravingsofafoodscientist.com/2018/10/18/meltsin-your-mouth- not-your-hand-but-why/.

18. Don't Worry Bee Happy Any Occasion Greeting Card | Cards. URL: https://www.pinterest.es/ pin/300193131417476290/.

19. Dove Vitalize. Women’s Health. №4. 2008. 17 p. URL: https://books.google.com.ua/books?id=1s UDAAAAMBAJ\&pg=PA $11 \& \operatorname{lpg}=\mathrm{PA} 11 \# \mathrm{v}=$ one page \&q\&f=false.

20. Dove Supreme Cream Oil Velvet Body Wash and Bar. Women's Health. № 4. 61 p. URL: https:// books.google.com.ua/books?id=1sUDAAAAM

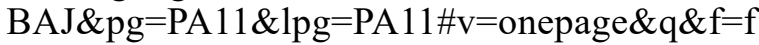
alse.

21. Enberg J. Nokia: Back to 'Connecting People' With Mobile Phones. Top-selling 3310 to make a comeback this summer. Insider Intelligence. 2017. URL: https://www.emarketer.com/Article/ Nokia-Back-Connecting-People-With-MobilePhones/1015338.

22. Everett J. I own a pair of rubber overalls. Women's Health. № 4.35 p. URL: https://books.google.com.ua/ books?id=1sUDAAAAMBAJ\&pg=PA11\&lpg=PA $11 \# \mathrm{v}=$ onepage $\& \mathrm{q} \& \mathrm{f}=$ false.

23. Everyone ages differently. Does your skincare know that? Women's Health. № 4.4 p. URL: https://books.google.com.ua/books?id=1sUDAA AAMBAJ\&pg $=$ PA11\&lpg $=$ PA11 $\mathrm{v}=$ onepage \&q $\& \mathrm{f}=$ false

24. 200 Famous car slogans and taglines. URL: https://sloganshub.org/car-slogans/.

25. Fauveau V. Journal of Diarrhoeal Diseases Research. International Centre for Diarrhoeal Disease Research, Bangladesh. Vol. 12. № 3. 1994. 255 p. URL: https://books.google.com.ua/ books? id=wWc8gLogQCkC\&pg=PA322\&lpg= PA322\&dq=Fauveau,Go+Ahead + with + AHEAD \&source.

26. Fiser D. Linguistic creativity in the language of print advertising / D. Fiser. Pardubice : Rezervovat. 2007. 194 p.

27. Have you ever had a bad time in Levi's. URL: https://www.flickr.com/photos/kahluacream/ 3259046574/in/photostream.

28. I Keep My Hands Clean! Why Can't He? URL: https://repository.duke.edu/dc/adaccess/BH1173.

29. Is Visa everywhere you want to be? URL: https://www.travelgumbo.com/topic/is-visaeverywhere-you-want-to-be.

30. Jaeger-LeCoultre. Traditional Jewelers. Orange Coast. № 3. 1995.7 p. URL: https:// 
books.google.com.ua/books?id=2f0DAAAAMB AJ\&pg=PA7\&lpg=PA7.

31. Kay and Zales Get New Advertising Agencies. URL: $\quad$ https://www.jckonline.com/editorialarticle/kay-zales-new-ad-agencies/.

32. Lee A. How Kit Kat Quickly Became One Of The World's Favorite Snacks. Referral Candy Blog. 2020. URL: https://www.referralcandy.com/blog/ kit-kat-marketing-strategy/.

33. Miss Clairol Hair Color Bath Campaign. URL: https://americancentury.omeka.wlu.edu/items/ show/89.

34. Mr Whipple: Please don't squeeze the Charmin! 20 years of TV commercial toilet paper drama. URL: https://clickamericana.com/topics/homegarden/mr-whipple-please-dont-squeeze-thecharmin.

35. New Dove Cream Oil Body Lotion. Women's Health. № 4. 2008. 65 p. URL: https://books. google.com.ua/books?id=1 sUDAAAAMBAJ\&p $\mathrm{g}=\mathrm{PA} 11 \& \operatorname{lpg}=\mathrm{PA} 11$.

36. Now blend away gray with the sure thing for a natural look. Ebony. №9. 1995. 27 p. URL: https://books.google.com.ua/books?id=ww3ikzft nNsC\&pg=PA27\&lpg=PA27\&dq.

37. Olay. Stop thinking cleansers just cleanse. Women’s Health. № 4. 2008. 11 p. URL: https:// books.google.com.ua/books?id=1sUDAAAAM BAJ\&pg=PA11\&lpg=PA11.

38. Pomegranate juice advert banned. Marie Claire. 2009. URL: https://www.marieclaire.co.uk/ life/health-fitness/pomegranate-juice-advertbanned-197435.

39. Pure Protein. Women’s Health. №4. 2008. 96 p. URL: https://books.google.com.ua/books?id=1s UDAAAAMBAJ\&pg=PA11\&lpg=PA11.

40. Sephora. URL: https://www.sephora.com/ product/high-potency-night-a-mins-tmresurfacing-cream-with-fruit-derivedahas-P434360.

41. Smoke ring. URL: https://www.adsoftheworld. com/media/print/smoke_ring.

42. The New Mac Pro "Beauty outside, beast inside". 2009. URL: http://futuregadget17.blogspot. com/2009/04/enhance.html.

43. The Supernova Cushion. Women's Health. № 4. 2008. 21 p. URL: https://books.google.com.ua/ books?id=1sUDAAAAMBAJ\&pg=PA $11 \&$ lpg=PA11.

44. Walton S. It's not TV, it's HBO. URL: https:// lotswife.com.au/its-not-tv-its-hbo/.

45. Welcome to Arizona Defensive Driving Online. URL: https://www.cheapeasyfastarizona.com/home.

46. Williams A. Tommy Gets Respect. New York. 1996. № 2. $24 \mathrm{p}$. URL: https://books.google.com.ua/ books? id=NeECAAAAMBAJ \&pg=PA 24 \&lpg=PA24.

47. Wouldn't You Really Rather Have a Buick? Buick Ads from 1913-1965. The Saturday Evening Post.
1913. URL: https://www.saturdayeveningpost.com/ 2017/02/wouldnt-really-rather-buick-buickads-1913-1965/.

48. YvesSaintLaurent Parfums. Special Issue. The Ultimate Insider's Guide to New York. № 4. 1987. 77 p. URL: https://books.google.com.ua/ books?id=pOMCAAAAMBAJ\&pg=PA7.

\section{REFERENCES}

1. Klyuev,E.V.(2001).Rhetoric(Invention.Disposition. Elocution) [Ritorika (Inventsiya. Dispozitsiya. El okutsiya)]: ucheb. pos. dlya vuzov. In Klyuev E.V. (ed.) M.: Izdatelstvo PRIOR, p. 272.

2. Kolisnychenko, T.V. (2020). Advertising discourse: concepts, features and functions [Reklamnyi dyskurs: poniattia, oznaky ta funktsii]. Zakarpatski filolohichni studii. Uzhhorod: Helvetyka, 13, 93-96.

3. Livshits, T.N. (1999). Specificity of advertising in pragmatic and linguistic aspects. [Spetsifika reklamyi v pragmaticheskom i lingvisticheskom aspektah]. (Master's thesis). Taganrog.

4. Muzikant, V.L. (1998). Theory and practice of modern advertising. [Teoriya $i$ praktika sovremennoy reklamyi]. In Muzyikant V.L. (ed.). M. : Evraziyskiy region, 12.

5. Snikhovska I.E. (2005). Mechanisms, means and methods of language play in modern English. [Mekhanizmy, zasoby ta pryiomy movnoi hry $\mathrm{v}$ suchasnii anhliiskii movi]. (Author's abstract). In Snikhovska I.E. (ed.). Zaporizhzhia.

6. Tkachuk-Miroshnychenko, O.Ye. (2001). Implication in advertising discourse (based on Englishlanguage commercial advertising). [Implikatsiia $\mathrm{V}$ reklamnomu dyskursi (na materiali anhlomovnoi komertsiinoi reklamy)]. (Master's thesis). In Tkachuk-Miroshnychenko O.Ye. (ed.).

7. Tyurina, S.Yu. (2009). About the concepts of advertising discourse and advertising text [O ponyatiyah reklamnyiy diskurs i reklamnyiy tekst]. Vestnik IGEU, 1, 1-3.

8. Allan, K., Burridge K. (1991). Euphemism and Dysphemism: language used as shield and weapon. Oxford : Oxford University Press.

9. Automobile Slogans. URL: https://www. advergize.com/slogans-list/car-slogans

10. Beale, B. (2003). Men can't help acting on impulse. ABC Science. URL: https://www.abc.net.au/ science/articles/2003/12/11/1007888.htm

11. Big Brands. Low prices. URL: https://www. facebook.com/brandmywrist/

12. Bittner, J. R. (ed.). (1996). Mass Communication. Boston: Allyn and Bacon.

13. Buratty, E. EBFitness. Stop curing health problems. Prevent them. URL: http:// ericburatty fitness.com/seven-days-withoutexercise-makes-one-weak/

14. (2008). Burn more fat. See more thin. Women's Health, 4, 169. URL: https://books.google.com.ua/ 
books?id=1sUDAAAAMBAJ\&pg=PA11\&lpg= $\mathrm{PA} 11 \# \mathrm{v}=$ onepage $\& \mathrm{q} \& \mathrm{f}=$-false

15. Chocolate Wiki. URL: https://chocolate.fandom. com/wiki/Almond_Joy

16. (2004). Cottonelle. Lab Tested for Gentless. Jet, 1, 29. URL: https://books.google.com.ua/books?id= 5LUDAAAAMBAJ\&pg=PA29\&lpg=PA29

17. Cravings of a Food Scientist. URL: https:// cravingsofafoodscientist.com/2018/10/18/meltsin-your-mouth-not-your-hand-but-why/

18. Don't Worry Bee Happy Any Occasion Greeting Card/Cards. URL: https://www.pinterest.es/ $\mathrm{pin} / 300193131417476290 /$

19. (2008). Dove Vitalize. Women's Health, 4, 17. URL: https://books.google.com.ua/books?id=1sUDA AAAMBAJ\&pg= PA11\&lpg=PA11

20. (2008). Dove Supreme Cream Oil Velvet Body Wash and Bar. Women's Health, 4, 61. URL: https://books.google.com.ua/books?id=1sUDAAAAMBAJ\&pg $=$ PA $11 \& 1 \mathrm{pg}=\mathrm{PA} 11 \& \mathrm{dq}=$

21. Enberg, J. (2017). Nokia: Back to 'Connecting People' With Mobile Phones. Top-selling 3310 to make a comeback this summer. Insider Intelligence. URL: https://www.emarketer.com/Article/Nokia-Back-Connecting-People-With-Mobile-Phones/1015338

22. Everett, J. (2008). I own a pair of rubber overalls. Women's Health, 4, 35. URL: https:// books.google.com.ua/books?id=1sUDAAAAMBAJ\&pg=PA11\&lpg=PA11

23. (2008). Everyone ages differently. Does your skincare know that? Women's Health, 4, 4. URL: https://books.google.com.ua/books?id=1sUDAAAAMBAJ\&pg=PA11\&lpg=PA11

24. 200 Famous car slogans and taglines. URL: https://sloganshub.org/car-slogans/

25. Fauveau, V. (1994). Journal of Diarrhoeal Diseases Research. International Centre for Diarrhoeal Disease Research, 12(3), 255. URL: https://books.google.com.ua/books?id=wWc$8 \mathrm{gLogQCkC} \& \mathrm{pg}=\mathrm{PA} 322 \& \operatorname{lpg}=\mathrm{PA} 322 \& \mathrm{dq}=$ Fauveau,Go+Ahead+with+AHEAD\&source

26. Fiser, D. (ed.). (2007). Linguistic creativity in the language of print advertising. Pardubice: Rezervovat.

27. Have you ever had a bad time in Levi's. URL: https://www.flickr.com/photos/kahluacream/3259046574/in/photostream

28. I Keep My Hands Clean! Why Can't He? URL: https://repository.duke.edu/dc/adaccess/BH1173

29. Is Visa everywhere you want to be? URL: https:// www.travelgumbo.com/topic/is-visa-everywhere-you-want-to-be

30. (1995). Jaeger-LeCoultre. Traditional Jewelers. Orange Coast, 3,7. URL: https:// books.google.com.ua/books?id=2f0DAAAAMBAJ\&pg=PA7\&lpg=PA7\&dq=

31. Kay and Zales Get New Advertising Agencies. URL: https://www.jckonline.com/editorial-article/kay-zales-new-ad-agencies/
32. Lee, A. (2020). How Kit Kat Quickly Became One Of The World's Favorite Snacks. Referral Candy Blog. URL: https://www.referralcandy. $\mathrm{com} / \mathrm{blog} /$ kit-kat-marketing-strategy/

33. Miss Clairol Hair Color Bath Campaign. URL: https://americancentury.omeka.wlu.edu/items/ show $/ 89$

34. Mr Whipple: Please don't squeeze the Charmin! 20 years of TV commercial toilet paper drama. URL: https:/clickamericana.com/topics/home-garden/mr-whipple-please-dont-squeeze-the-charmin

35. (2008). New Dove Cream Oil Body Lotion. Women's Health, 4, 65. URL: https:// books.google.com.ua/books?id=1sUDAAAAMBAJ\&pg=PA11\&lpg=PA11

36. (1995). Now blend away gray with the sure thing for a natural look. Ebony, 9, 27. URL: https:// books.google.com.ua/books? id=ww3ikzftnNsC\&pg=PA27\&lpg $=$ PA27\&dq.

37. (2008). Olay. Stop thinking cleansers just cleanse. Women's Health, 4, 11. URL: https:// books.google.com.ua/books?id=1sUDAAAAMBAJ\&pg=PA11\&lpg=PA11.

38. (2009). Pomegranate juice advert banned. Marie Claire. URL: https://www. marieclaire.co.uk/life/health-fitness/pomegranate-juice-advert-banned-197435

39. (2008). Pure Protein. Women's Health, 4, 35. URL: https://books.google.com.ua/books?id=1sUDAAAAMBAJ\&pg=PA11\&lpg=PA11

40. Sephora. URL: https://www.sephora.com/product/high-potency-night-a-mins-tm-resurfacingcream-with-fruit-derived-ahas-P434360

41. Smoke ring. URL: https://www.adsoftheworld.com/ media/print/smoke ring

42. (2009). The New Mac Pro «Beauty outside, beast inside». URL: http://futuregadget 17.blogspot.com/ 2009/04/enhance.html

43. (2008). The Supernova Cushion. Women's Health, 4, 21. URL: https://books.google.com.ua/books?id=1sUDAAAAMBAJ\&pg=PA11\&lpg=PA11

44. Walton, S. It's not TV, it's HBO. URL: https:// lotswife.com.au/its-not-tv-its-hbo/

45. Welcome to Arizona Defensive Driving Online. URL: https://www.cheapeasyfastarizona.com/home

46. Williams, A. (1996). Tommy Gets Respect. New York, 2, 24. URL: https://books.google.com.ua/ books? id=NeECAAAAMBAJ\&pg=PA24\&lp$\mathrm{g}=\mathrm{PA} 24$

47. (1913). Wouldn't You Really Rather Have a Buick? Buick Ads from 1913-1965. The Saturday Evening Post. URL: https://www. saturdayeveningpost.com/2017/02/wouldnt-really-rather-buick-buick-ads-1913-1965/

48. (1987). YvesSaintLaurent Parfums. Special Issue. The Ultimate Insider's Guide to New York, 4, 77. URL: https://books.google.com.ua/ books?id=pOMCAAAAMBAJ\&pg=PA73\&lp$\mathrm{g}=\mathrm{PA} 7$ 